\title{
ЕКОНОМІЧНА ПІДГОТОВКА СТАРШОКЛАСНИКІВ У ПРОЦЕСІ ПРОФІЛЬНОЇ ТЕХНОЛОГІЧНОЇ ОСВІТИ
}

\author{
Кулішов В. С. Економічна підготовка старшокласників у процесі профільної технологічної \\ освіти. \\ У статті розглянуто передумови здійснення та роль економічної підготовки учнів старшої \\ школи у процесі профільної технологічної освіти відповідно до сучасних тенденцій розвитку \\ суспільства. \\ Ключові слова: профільне навчання, економічна підготовка, технологічна освіта, виробничі \\ відносини, профільна економічна підготовка, продуктивна праця.
}

Кулишов В. С. Экономическая подготовка старшеклассников в процессе профильного технологического образования

В статье рассмотрены предпосылки осуществления и роль экономической подготовки учащихся старшей школы в процессе профильного технологического образования в соответствии с современными тенденциями развития общества.

Ключевые слова: профильное обучение, экономическая подготовка, технологическое образование, производственные отношения, профильная экономическая подготовка, производительный труд.

Kulishov V. S. Economic training of senior pupils in the process of profile technology education.

The article reviews the prerequisites of the economic role and training of senior school pupils in the profile of technological education in accordance with modern trends in society.

Key words: profile education, economic training, technology education, industrial relations, economic profile training, productive work.

Зміни, що відбуваються в сучасному суспільстві, ведуть до того, що в соціальному житті й діяльності найбільш значущими та важливими постають такі якості особистості, як: ініціативність, креативність, комунікативність, гнучкість мислення, уміння співпрацювати з іншими, робити вибір, шукати інформацію й опрацьовувати іiі, особиста відповідальність, здатність до зміни видів діяльності, адаптивність. Життя вимагає, аби людина сама вміла шукати інформацію, потребує від неї здатності працювати в команді, розуміти людей, вести діалог. Такі вміння та якості дитина має набувати ще в процесі шкільного навчання, що, на жаль, на практиці нині не реалізується достатньою мірою [5, c. 3-4].

Крім того, поза увагою залишається ще одна важлива функція шкільної освіти, що $є$ надто актуальною в нашому інформаційно-технологізованому суспільстві - функція практичного використання отриманих знань. Не знання заради заліку, іспиту чи позитивної оцінки, а знання як методологія, основа поведінки та діяльності. У технології навчальної діяльності учнів має бути закладена практична орієнтованість знань, бо інакше вони просто забуваються, тому що не використовуються. Ми йдемо до суспільства знань, а точніше - до знаннєвого суспільства, а воно не там, де багато інформаційних складників, носіїв, хоча це необхідна умова. Знаннєве суспільство там, де знаннєва людина, людина, яка може жити, працювати, діяти професійно, і в побуті, і в громадсько-політичній сфері на основі отриманих знань. Процес навчання має забезпечити підготовку такого вихованця, котрий зможе знайти себе, компетентно обрати життєвий шлях, враховуючи при цьому особисті можливості, прийняти рішення про подальшу професійну діяльність.

Тому одним з ефективних шляхів розв'язання цих та інших проблем шкільної освіти $€$ нещодавно запроваджене профільне навчання у старшій школі. Профільне навчання прийшло на зміну поглибленому вивченню окремого предмета або групи суміжних 
предметів, що значною мірою грунтується на знаннєвій парадигмі. За своїми істотними ознаками воно відрізняється від поглибленого вивчення предметів, а спроби реалізувати принципи і підходи профільного навчання в класах з поглибленим вивченням окремих предметів приводять до негативних наслідків, зокрема до перевантаження учнів.

Здійснений аналіз наукових джерел свідчить про те, що в сучасній педагогічній теорії проблема обгрунтування ідеї диференціації освіти та організації профільного навчання у ЗНЗ достатньо розроблена (Л. Березівська, Н. Бібік, М. Бурда, Л. Денисенко, Г. Єгоров, Л. Калініна, В. Кизенко, О. Корсакова, Л. Онищук, С. Трубачева [6; 1], О. Пометун [5], П. Сікорський [8]).

Meта статmi - проаналізувати передумови здійснення та роль економічної підготовки учнів старшої школи у процесі профільної технологічної освіти.

Профільне навчання - вид диференційованого навчання, який передбачає врахування освітніх потреб, нахилів і здібностей старшокласників, створення умов їх професійного самовизначення. Забезпечується профільне навчання за рахунок змін у цілях, змісті, структурі та організації навчального процесу та грунтується на основних положеннях Концепції профільного навчання в старшій школі. Мета профільного навчання забезпечення можливостей для рівного доступу учнівської молоді до здобуття загальноосвітньої професійної та початкової допрофесійної підготовки, виховання особистості, здатної до самореалізації, професійного зростання й мобільності в умовах реформування сучасного суспільства. Профільне навчання спрямоване на набуття старшокласниками навичок самостійної науково-практичної, дослідницько-пошукової діяльності, розвиток їх інтелектуальних, психологічних, творчих, моральних, фізичних, соціальних якостей, прагнення до саморозвитку та самоосвіти [2, с. 743].

Сучасна реструктуризація старшої школи як профільної має грунтуватись на серйозних якісних змінах як під час формування змісту освіти, так і під час відбору методів та форм організації навчального процесу, а також у підготовці кадрів. Профільне навчання буде ефективними, якщо у його процесі учні осмислюватимуть не лише процеси і явища навколишньої дійсності, але і пізнаватимуть власну індивідуальність, розвиватимуть власну особистість, здійснюватимуть відповідний своєму внутрішньому світові вибір майбутньої професійної діяльності.

Найкращою, на сьогодні, загальноосвітньою практикоорієнтовною підготовкою учнів $є$ профільне технологічне навчання, професійна спрямованість якого систематизує знання предметів цієї освітньої галузі, актуалізує утримання і забезпечення навчального процесу, підвищує особистісну мотивацію, ініціює додаткову освітню та самостійну практичну діяльність учнів. Технологічна освіта в старшій школі передбачає ознайомлення 3 сучасними галузевими технологіями, отримання знань і вмінь виконання узагальнених технологічних операцій, розвиток навичок навчання, творчого мислення і вирішення практичних завдань, формування професійно значущих якостей особистості у взаємодії 3 основними об'єктами праці в базових галузях економічної діяльності, досягнення ефективного рівня професійної культури, що забезпечує виявлення професійних інтересів і схильностей для визначення подальшого освітнього напряму учня.

Традиційно прийнятою в профільній технологічній освіті є орієнтація, в основному, на трудову підготовку підростаючого покоління. Однак, у силу того, що змінюються економічні основи суспільного життя, коли необхідність виробничих процесів диктується не державою, а реаліями життя, стихією ринку, старий підхід до організації навчальновиховного процесу потребує докорінної зміни. Якісні перетворення в соціальній структурі суспільства, впровадження нового господарського механізму ставлять нові вимоги до молоді, яка вступає в самостійне життя. Тенденції трудової політики потребують професіональної мобільності, готовності до змін праці, в окремих випадках професії та сфери діяльності при зміні життєвих обставин. Ринкові умови висувають, поряд із завданням трудової підготовки підростаючого покоління, забезпечення практичної, морально-психологічної та інтелектуальної готовності до активної життєдіяльності, 
забезпечення соціальної захищеності молодих працівників в умовах конкуренції робочої сили та можливого безробіття. Тому формування повноцінної, усебічно розвиненої, самодостатньої особистості неможливе без створення системи економічної освіти i виховання у межах технологічного профілю навчання. Адже вміння проводити економічні операції закладається не лише на уроках математики, географії чи суспільствознавства, а передовсім у трудовій діяльності учнів, що має характер найбільш практичного застосування економічних знань. I навпаки - жодне завдання економічної освіти та виховання не може реалізуватись у відриві від трудової діяльності. Йдеться про справжнє, а не формальне включення учнів у виробничі відносини для того, щоб вони здобували життєві уявлення про працю, iї характер, трудову дисципліну, зарплату.

У процесі розвитку нових тенденцій соціально-економічної діяльності особливо актуальною $\epsilon$ проблема формування і розвитку особистості, готовності працювати компетентно в майбутній професійній діяльності. Завданням профільного навчання $\epsilon$ поєднання загальної середньої освіти школярів з поглибленим засвоєнням економічних знань i вмінь практично застосовувати їх у допрофесійній i майбутній професійній діяльності. Профільна економічна підготовка учнів старших класів до роботи в умовах ринкової економіки потребує оволодіння ними організаторськими уміннями, творчими підходами та активною життєвою позицією, орієнтованими, зокрема, на співробітництво, підприємництво, комунікативність, прийняття рішень, адаптивність до демократичних форм організаторської діяльності.

Що ж взагалі треба розуміти під категорією «економічна підготовка»? Дану проблему розглядало чимало педагогів-дослідників, психологів, економістів. Так, І. Прокопенко вважає, що економічна підготовка має бути спрямованою на формування економічної культури та інтенсифікації роботи 3 підготовки молоді до входження у життя та включення її в трудову діяльність. Виходячи з цієї мети, дослідник визначив такі завдання економічної підготовки школярів: формування системних економічних знань та знань про закони, правила і норми стосунків між людьми, які виникають у процесі економічної діяльності, та формування умінь використовувати їх на практиці; формування умінь орієнтуватися у економічній ситуації, вміння приймати рішення з конкретної проблеми, робити критичний аналіз ситуації тощо [7, с. 221-224].

На думку О. Архіпова, метою економічної підготовки школярів $\epsilon$ формування економічного мислення, яке визначається знанням побудови економічної дійсності та усвідомлення свого місця у ній, засвоєння норм цивілізованої економічної поведінки, економічної культури, виробленням навичок відповідної економічної діяльності [11].

А. Нісімчук та О. Падалка вважають, що основним завданням економічної підготовки слід вважати формування в учнів нового економічного мислення. Зміст економічної підготовки учнів загальноосвітніх шкіл автори розглядають як систему економічних знань, певних навичок і вмінь, спрямованих на вироблення економічної свідомості особистості школяра, його світогляду, поглядів і переконань [4, с. 178].

На думку О. Аксьнової, В. Мельченко, Н. Тітової головною метою економічної підготовки учнів $є$ формування економічної культури. При цьому економічна свідомість розглядається ними як їі елемент, а економічне мислення - як один 3 проявів економічної культури [12, с. 118-121].

Найбільш оптимальний варіант відповіді на запитання, що розглядається, був, на наш погляд, даний професором О. Шпаком. Він зазначає, що під змістом економічної підготовки учнів треба розуміти систему економічних знань, певних умінь і навичок їх творчого практичного застосування, які забезпечують підготовку молодого покоління до реального життя [10]. Тому, у контексті технологічного профілю навчання дане формулювання поняття економічної підготовки підростаючого покоління вважаємо найбільш прийнятним. Більше того, воно визначає сутність терміну профільна економічна підготовка з їі практикоорієнтовною, професійно-підготовчою спрямованістю. 
Вивчення наукової літератури та практичного досвіду з даної проблематики дало змогу нам сформулювати визначення поняття профільної економічної підготовки старшокласників, під яким ми розуміємо систему економічних знань, певних умінь i навичок їх творчого практичного застосування, спрямованих на формування економічної свідомості та економічного мислення, світогляду, поглядів та переконань, економічної культури. Вважаємо, що лише за умов сформованості зазначених якостей у випускника школи, ліцею, гімназії, колегіуму відповідного профільного спрямування, його подальше успішне професійне навчання та продуктивна робота постануть пріоритетом майбутнього професійного вибору.

Теоретичний аналіз проблеми, вивчення передового вітчизняного та зарубіжного досвіду дозволили сформулювати основні концепційні положення перебудови традиційної трудової підготовки школярів у більш прогресивну, економічно-орієнтовну з урахуванням iii сучасної прогностичної функції: варіативність змісту і форм організації трудового навчання та виховання учнів 3 врахуванням соціально-економічних особливостей суспільства, національних трудових традицій, нахилів учнів; зв'язок навчання з суспільнокорисною, у тому числі виробничою працею, як основа формування досвіду трудових відносин та якостей особистості, які полегшують адаптацію і самовизначення випускників в умовах ринкової економіки; посилення уваги до мотиваційно-потребної сфери особистості, формулювання економічних знань та умінь, досвіду організаційногосподарської діяльності; систематичне вивчення стану та ефективності процесу трудової підготовки з метою обумовленого планування, своєчасного коректування педагогічних впливів і реалізації диференційованого підходу до учнів.

Тенденції сучасної трудової політики, впровадження інновацій і принципово нових технологій, скорочення строків оновлення інформації, що випереджають етапи становлення особистості, виявили дефіцит функціональної грамотності, тобто практичну непідготовленість значної частини випускників навчальних закладів до праці в нових умовах. У тому числі, відчувається дефіцит знань і з економіки в учнів старших класів. Випускник сучасної школи повинен володіти економічними категоріями, знати основи винахідницької діяльності, інформацію як джерело знань, інформатику, поняття менеджменту та маркетингу, фермерське господарство, або вибирати той напрям, який традиційно склався в регіоні, навчальну базу та інші фактори, що впливають на підготовку учнівської молоді до трудової діяльності.

Через це, в умовах ринкових відносин проблема зайнятості населення, конкурентоздатності на біржі праці та дієздатності в обраній сфері діяльності потребує від молоді, що вступає в життя, цілого комплексу показників їх функціональної грамотності, поміж яких О. Шпак виокремлює такі: формування загальних орієнтовних основ будь-якої діяльності: планування, раціональна організація діяльності, контроль і аналіз результатів, що підвищують продуктивність та якість праці; загально-трудові, політехнічні знання та вміння, технічна культура, які забезпечують професійну мобільність, готовність до змін праці, підвищення кваліфікації і при необхідності перекваліфікації; економічні знання і вміння, навички організаційно-господарської діяльності, що лежать в основі заповзятливості, готовності до самостійного прийняття рішень в умовах ринкових відносин [9, с. 11].

Сучасна економічна освіта та виховання учнів спираються на знання 3 багатьох загальноосвітніх дисциплін, тому одночасне виявлення економічних знань у програмах більшості шкільних курсів сприяє поглибленню процесу пізнання і підготовці учнів до життя та праці в умовах ринкової економіки. У цьому аспекті освітня галузь «Технологія» становить такі змістовні лінії: економіка сімейного господарства, основи підприємницької діяльності, умови продуктивної трудової діяльності (оволодіння спільними основами діяльності, спільно з трудовими і спеціальними вміннями, культурою праці) і створює предметну основу для практичного використання економічних знань і вмінь. Під час економіки в загальноосвітній школі учні одержують знання та уявлення про економічні 
явища та категорії, розвиток української держави в минулому, сучасному та майбутньому. А тісний зв'язок економіки з багатьма дисциплінами, які вивчаються в школі, підвищує зацікавленість учнів до самостійності, формування особистості з розвинутими поглядами на вибір майбутньої професії і трудової діяльності.

Основною ідеєю нової системи трудової та економічної підготовки учнівської молоді $є$ поєднання навчання 3 індивідуальною та колективною суспільно корисною, продуктивною працею чи громадською діяльністю. Сутність трудового та економічного виховання учнівської молоді полягає в формуванні в неї готовності до самостійного життя та праці для забезпечення свого добробуту і високих темпів соціального та науковотехнічного прогресу. У відповідності до цього кожна молода людина, що стає на шлях самостійного трудового життя, повинна мати всебічний інтелектуальний та фізичний розвиток, наукове світосприйняття, глибокі знання науково-технічних та економічних основ сучасного виробництва, а також свідомо і творчо долучатися до суспільно корисної та продуктивної праці [3].

Беручи участь в продуктивній праці, учні дістають уявлення про власність, бізнес-план, заробітну плату, виробничу i технологічну дисципліну, а також про такі економічні поняття, як собівартість, коефіцієнт трудової участі, продуктивність праці. Тільки завдяки взаємообумовленості змісту економічної підготовки та трудового виховання школярів кожний випускник навчального закладу зможе з'ясувати для себе, що для підвищення життєвого рівня треба краще працювати. Одержання економічних знань прискорює формування у молоді спеціальної зрілості, становлення активної життєвої позиції, підприємливості.

Практика переконує, що потрібно ширше впроваджувати досвід економічної підготовки у старшій профільній школі та залучати учнів до обговорення виробничотехнічних питань, що стосуються винахідництва та раціоналізаторства, самостійного пошуку найкращих варіантів організації праці, застосування знань та умінь дослідницького та проблемно-аналітичного характеру. Трудовий процес необхідно організувати таким чином, щоб учні могли набути соціального та виробничого досвіду.

\section{Література}

1. Бібік Н. М. Профільна школа: проблеми наукового супроводження / Надія Михайлівна Бібік // Зміст і технології шкільної освіти: матеріали звітної наукової конференції Інституту педагогіки АПН України 30-31 березня 2004 р. - К.: Педагогічна думка, 2004. - С. 6-9. 2. Енциклопедія освіти / В. Г. Кремінь (гол. ред.). - К.: Юрінком Інтер, 2008. - 1040 с. 3. Мадзігон В. М. Продуктивна педагогіка. Монографія / Василь Мадзігон. - К. : Вересень, 2004. - 324 с. 4. Нісімчук А. С. Сучасні педагогічні технології : навчальний посібник / А. С. Нісімчук, О.С.Падалка, О. Т. Шпак- К. : Видавничий центр «Просвіта», 2000. - 368 с. 5. Пометун О. Старша школа: проблеми формування змісту й організації навчальної діяльності учнів / О. Пометун // Рідна школа. - 2011. - № 6. - С. 3-7. 6. Про затвердження нової редакції Концепції профільного навчання у старшій школі: наказ ... від 11. 09. 2009 р. № 854 // Інформаційний збірник Міністерства освіти і науки України. - 2009. - № 28-29. - С. 57-64. 7. Производительный труд // Большая советская энциклопедия / Гл.ред. М. П. Прохоров. Т. 21. - М.: Советская энциклопедия, 1975. - 640 с. 8. Сікорський П. І. Профілізація старшої школи у контексті професійної підготовки учнів / П. І. Сікорський // Педагогіка і психологія професійної освіти. - 2009. - № 3. - С. 46-51. 9. Шпак О. Т. Вивчення і оцінка рівня економічної підготовки учнів: питання теорії і методики: навч. пос. / О. Т. Шпак, С. Г. Цибін, В. М. Городній, В. І. Терес; НПУ ім. М. П. Драгоманова. - К. : Четверта хвиля, 2001. - 127 с. 10. Шпак О. Т. Економічна підготовка педагогічних кадрів в системі безперервної освіти / НПУ ім. Драгоманова. - К. : Четверта хвиля, 2000. - 352 с. 11. Экономическая теория в школе / Под ред. Л. А. Гусева. Ростов-на-Дону : Феникс, 1996. - 544 с. 12. Экономическое воспитание и образование молодежи / [Составители: А. В. Антонюк, В. А. Мельченко]. - К. : Молодь, 1986. - 184 с. 